\title{
Synthesis of Porous Polymer Carrier and Immobilization of $\alpha$-Chymotrypsin
}

\author{
Guoliang TAO and Shintaro FurUSAKI* \\ Department of Chemical Engineering, The University of Tokyo, \\ Tokyo 113, Japan
}

(Received April 13, 1994)

\begin{abstract}
A porous resin, acrolein-vinyl acetate-divinyl benzene copolymer, was synthesized by radical suspension polymerization of acrolein with vinyl acetate and divinylbenzene in the presence of a pore-creating agent, toluene. A porous polymer carrier containing both anilino and hydroxy groups was obtained by further reaction of the resin with $p$-nitroaniline, then reduction of the nitro group to amino group. $\alpha$-Chymotrypsin was immobilized on the porous polymer carrier by the glutaraldehyde-crosslinking method or diazo-coupling method. The activity recovery and relative activity of the immobilized $\alpha$-chymotrypsin were determined when L-tyrosine ethyl ester and casein were selected as low and high molecular weight substrates, respectively. At the same time, the stability, resistance against inhibition, the Michaelis constant $K_{\mathrm{m}}$, and reusability of the immobilized enzyme were also investigated. The results indicated that the immobilized $\alpha$-chymotrypsin had not only higher relative activity, but also remarkable stability and better reusability. In addition, the immobilized $\alpha$-chymotrypsin had stronger resistance against $\mathrm{Cu}^{2+}$ inhibition.

KEY WORDS Immobilization / $\alpha$-Chymotrypsin / Immobilized Enzyme /

Porous Polymer Carrier / Enzyme Activity /
\end{abstract}

Since the recovery yield and the reusability of native enzymes are quite limited as industrial catalysts, attention has been paid to the enzyme immobilization, ${ }^{1}$ which offers advantages over native enzymes in batch or continuous processes due to controlled product formation, ease of enzyme removal from the reaction system, and adaptability to various engineering designs. Enzymes are usually stabilized by immobilization. In particular, immobilized proteases are often more stable than native proteases owing to protection from autolysis. The immobilization of proteases, therefore, permits their use in broad range.

$\alpha$-Chymotrypsin (EC 3.4.21.1) is one of the proteases applied widely. It catalyzes the hydrolysis of peptide bonds where the acyl donor component is an aromatic amino acid.
This protease also catalyzes the synthesis of peptide bonds with the same specificity. After being immobilized, $\alpha$-chymotrypsin offers great advantages in its use in cosmetics, ${ }^{2}$ food science, ${ }^{3}$ analytical chemistry, ${ }^{4}$ organic synthesis, and peptide synthesis. ${ }^{5}$

In this study, we select polyacroleinpolyvinyl alcohol copolymer as a matrix material to study the $\alpha$-chymotrypsin immobilization. We selected the copolymer as an immobilization matrix for two primary reasons. First, since effects of polymer carriers on the activity of enzymes have not been studied in detail until now, we investigated the influences of selected matrix construction on the activity and properties of immobilized enzyme. Second, in comparison with circumstances of polyacrolein as a carrier, ${ }^{6,7}$ we can

* To whom correspondence should be addressed.

Guoliang Tao is on leave from Wuhan University (China). 
adjust and improve the hydrophilic property of the matrix by introducing hydroxyl group into the matrix construction. Thus, the immobilized enzyme prepared with this matrix might be applied to various conditions such as reactions in organic solvents. At present, the operation of enzymes in extreme nonphysiological environments, particularly in organic and aqueous/organic solvents, is of significant interest to both science and industry. ${ }^{8-10}$

In this study, the porous resin Ac-VAc-DVB copolymer was synthesized by radical suspension polymerization of acrolein (Ac) with vinyl acetate (VAc) and divinylbenzene (DVB) in the presence of a pore-creating agent. A kind of porous polymer carrier containing both anilino and hydroxyl groups was obtained by further reaction of the resin with $p$-nitroaniline, then reduction of nitro group to amino group. $\alpha$-Chymotrypsin was immobilized on the porous polymer carrier by the glutaraldehydecrosslinking method or diazo-coupling method. The activity recovery and relative activity of the immobilized $\alpha$-chymotrypsin were determined when L-tyrosine ethyl ester and casein were selected as low and high molecular weight substrate, respectively. Some factors which affect enzyme immobilization were studied. At the same time, the stability, resistance against inhibition, the Michaelis constant $K_{\mathrm{m}}$, and reusability of the immobilized enzyme were also investigated.

\section{EXPERIMENTAL}

\section{Materials}

$\alpha$-Chymotrypsin was obtained from bovine pancreas (Wako Chem. Co., Ltd.), 1000 USP units/mg. Acrolein (Wako Chem. Co., Ltd.), $90 \%$, was redistilled before use. Purity of vinyl acetate (Wako Chem. Co., Ltd.) was 98\%, divinylbenzene (Tokyo Kasei Kogyo Co., Ltd.) $55 \%$ (mixture of isomers), diallyl ether (Aldrich Chem. Co.) $99 \%$. L-Tyrosine ethyl ester hydrochloride and casein were products of Wako Chem. Co., Ltd., Tokyo. All other reagents were purchased from Wako Chem. Co., Ltd. and Tokyo Kasei Kogyo Co., Ltd.

\section{Instruments}

Measurement of UV spectra was carried out with a Shimadzu UV-180 spectrophotometer, FT-IR spectra with a Shimadzu FTIR-4000 spectrophotometer, and SEM with JEOL JSM-T300 scanning microscope. Elemental analysis value was determined with Yanagimoto $\mathrm{CHN}$ corder MT-5.

\section{Methods}

Synthesis of Porous Resin. $6.7 \mathrm{~g}$ Acrolein $(0.12 \mathrm{~mol}), 3 \mathrm{~g}$ vinyl acetate $(0.035 \mathrm{~mol}), 2.7 \mathrm{~g}$ divinylbenzene $(0.021 \mathrm{~mol}), 0.45 \mathrm{~g}$ azobisisobutyronitrile (AIBN, $0.0027 \mathrm{~mol}$ ) and $10 \mathrm{ml}$ toluene, which is the pore-creating agent, were mixed well and put into refrigerator for overnight (oil phase). Into a three-necked flask equipped with a stirrer, a reflux condenser and a thermometer, $80 \mathrm{ml}$ water containing $0.18 \mathrm{~g}$ soluble starch (dispersed phase) was added. The mixture was heated to $45^{\circ} \mathrm{C}$, then the above oil phase was added into the reaction flask. The reaction system was stirred at $50^{\circ} \mathrm{C}$ for $10-12$ hours and at $75^{\circ} \mathrm{C}$ for $10-12$ hours. The product was filtered, washed with distilled water, acetone and hot water, then dried.

Preparation of Porous Polymer Carrier. The preparation of polymer carrier is shown as Scheme 1.

$5 \mathrm{~g} p$-Nitroaniline was dissolved in $50 \mathrm{ml}$ dioxane containing $4 \mathrm{ml} 1 \mathrm{~N}$ hydrochloric acid. $4 \mathrm{~g}$ of the resin was added into this solution, stirred with reflux for 20 hours. The product was filtered, washed with distilled water, ethanol, and acetone, then dried.

The nitro group was reduced by sodium hydrosulfite according to ref 11 .

Immobilization of $\alpha$-Chymotrypsin. $\alpha$-Chymotrypsin was immobilized on the porous polymeric carrier in the following three methods. 


$$
\begin{aligned}
& \mathrm{CH}_{2}=\mathrm{CH}-\mathrm{CHO}+\mathrm{CH}_{2}=\mathrm{CH}-00 \mathrm{CCH}_{3}+\mathrm{CH}_{2}=\mathrm{CH}-\mathrm{X}-\mathrm{CH}=\mathrm{CH}_{2} \frac{\text { Copolymerization }}{\mathrm{AIBN}} \\
& -\left.\right|_{-\mathrm{CH}_{2}-\mathrm{CH}-\mathrm{CH}_{2}-} ^{-\mathrm{CH}_{2}-\mathrm{CH}-\mathrm{CH}_{2}-\mathrm{CH}-\mathrm{CH}_{2}-\mathrm{CH}-} \\
& -\mathrm{CH}_{2}-\left.\left.\right|_{\mathrm{X}} ^{\mathrm{CH}-\mathrm{CH}_{2}-\mathrm{CH}_{2}-\mathrm{CH}_{2}-\mathrm{CH}-}\right|_{\mathrm{CH}=\mathrm{N}-\mathrm{O}-\mathrm{NO}_{2}-\mathrm{Na}_{2}-\mathrm{CH}-\mathrm{CH}_{2}-\mathrm{CH}-\mathrm{CH}_{2}-\mathrm{CH}-} \\
& --\mathrm{CH}_{2}-\mathrm{CH}_{2}-\mathrm{CH}_{2}-\mathrm{CH}-\mathrm{CH}_{2}-\mathrm{CH}-\mathrm{CH}-\mathrm{CH}-\mathrm{CH}_{2}-\mathrm{CH}- \\
& x=-\mathrm{O}, \quad-\mathrm{CH}_{2}-\mathrm{O}-\mathrm{CH}_{2}-
\end{aligned}
$$

Scheme 1.

$$
\begin{aligned}
& \mathrm{OHC}-\left(\mathrm{CH}_{2}\right)_{3}-\mathrm{CHO}+\mathrm{NH}\left(\mathrm{CH}_{2} \mathrm{CH}_{2} \mathrm{OH}\right)_{2} \\
& \mathrm{OHC}-\left(\mathrm{CH}_{2}\right)_{3}-\mathrm{CH}(\mathrm{OH})-\mathrm{N}\left(\mathrm{CH}_{2} \mathrm{CH}_{2} \mathrm{OH}\right)_{2} \\
& \text { 1. } \mathrm{P}-\mathrm{CH}=\mathrm{N}-\mathrm{O}-\mathrm{NH}_{2} \\
& \text { 2. } \mathrm{HCl} \\
& \mathrm{P}-\mathrm{CH}=\mathrm{N}-\mathrm{O}-\mathrm{CH}-\left(\mathrm{CH}_{2}\right)_{3}-\mathrm{CHO} \\
& \mathrm{P}-\mathrm{CH}=\mathrm{N}-\mathrm{O}-\mathrm{CH}-\left(\mathrm{CH}_{2}\right)_{3}-\mathrm{CH}=\mathrm{N}-\text { Enzyme }
\end{aligned}
$$

Scheme 2.

\section{1) Glutaraldehyde-Crosslinking Method}

$50 \mathrm{mg}$ Carrier was suspended in $2 \mathrm{ml}$ $0.05 \mathrm{moll}^{-1}$ Tris- $\mathrm{HCl}$ buffer (pH 7.0). $\alpha$ Chymotrypsin $(1 \mathrm{mg})$ and $0.22 \mathrm{ml}$ of $2.5 \%$ glutaraldehyde solution were added. The mixture was shaken at room temperature for 6 hours. The product was then filtered, washed with a large amount of Tris- $\mathrm{HCl}$ buffer and distilled water, then dried at low temperature. The final product was stored at $4^{\circ} \mathrm{C}$.

2) Improved Glutaraldehyde-Crosslinking Method

This immobilization method is shown as Scheme 2. $3 \mathrm{ml} \mathrm{25 \% -Glutaraldehyde} \mathrm{and} 3 \mathrm{ml}$ 2',2-iminodiethanol were mixed well and shaken at $25^{\circ} \mathrm{C}$ for 30 minutes. Then, $1.5 \mathrm{~g}$ of the carrier was added, and the mixture was continuously shaken for 2 hours. The product was filtered and washed with distilled water. The product was transferred into a flask containing $10 \mathrm{ml} 0.1 \mathrm{~N}$-hydrochloric acid, and the mixture was shaken at $25^{\circ} \mathrm{C}$ for 30 minutes. The carrier derivative was filtered and washed with distilled water, then dried.

The above carrier derivative $100 \mathrm{mg}$ was suspended in $2 \mathrm{ml} 0.05 \mathrm{moll}^{-1}$ Tris- $\mathrm{HCl}$ buffer (pH 7.0) containing $2 \mathrm{mg} \alpha$-chymotrypsin. The mixture was shaken at room temperature for 4 hours. Subsequent procedures are the same as those in method 1.

\section{3) Diazo-Coupling Method}

Carrier diazonium salt derivative was prepared according to the method of ref 13 . $100 \mathrm{mg}$ Carrier diazonium salt was suspended 
in $2 \mathrm{ml} 0.05 \mathrm{moll}^{-1}$ Tris-HCl buffer ( $\mathrm{pH} 7.0$ ) containing $2 \mathrm{mg} \alpha$-chymotrypsin. The mixture was stirred at $0^{\circ} \mathrm{C}$ for 2 hours, then at $4^{\circ} \mathrm{C}$ for 20 hours. Subsequent procedures are the same as those in method 1.

Assay for Enzyme Activity. Assay for $\alpha-$ chymotrypsin activity were essentially carried out according to ref 12 .

1) Determination with L-TEE (L-Tyrosine Ethyl Ester) as a Substrate

The reaction mixture consisted of $2.9 \mathrm{ml}$ $0.002 \mathrm{moll}^{-1} \mathrm{~L}$-TEE in $0.05 \mathrm{moll}^{-1}$ Tris buffer (containing $0.02 \mathrm{moll}^{-1} \mathrm{Ca}^{2+}, \mathrm{pH} 7.0$ ) and $0.1 \mathrm{ml}$ free enzyme solution $\left(1 \mathrm{mg} \mathrm{ml}^{-1}\right)$. After incubating the reaction mixture for 3 minutes at $25^{\circ} \mathrm{C}$, the change of the UV-absorbance of the reaction mixture at $234 \mathrm{~nm}$ was determined.

2) Determination with Casein as a Substrate

The reaction mixture consisted of $0.9 \mathrm{ml}$ of $0.1 \mathrm{moll}^{-1}$ borate buffer ( $\mathrm{pH} 8.0$ ), $0.1 \mathrm{ml}$ free enzyme solution $\left(0.05 \mathrm{mg} \mathrm{ml}^{-1}\right)$, and $1 \mathrm{ml}$ pre-warmed $1 \%$-casein solution (containing $0.005 \mathrm{moll}^{-1} \mathrm{Ca}^{2+}$ at $\mathrm{pH} 8.0$ ). The reaction mixture was incubated for 20 minutes at $35^{\circ} \mathrm{C}$. $3 \mathrm{ml} \mathrm{5 \%}$-trichloroacetic acid was added to this mixture. The precipitate was filtered off and the absorbance of the filtrate at $280 \mathrm{~nm}$ was determined.

The assay for the immobilized enzyme activity was almost the same as that for free enzyme, but the medium was needed to be agitated. In all experiments to determine the immobilized enzyme activity, the relevant carrier was used as a control in determining the absorbance of the immobilized enzyme.

\section{RESULTS AND DISCUSSION}

\section{Synthesis of Porous Resin}

In this study, polymer resins were synthesized as described above by radical suspension polymerization of acrolein or acrolein with vinyl acetate in the presence of a bifunctional monomer, as a crosslinking agent. The polymer resin was prepared under various polymerization conditions. The typical experimental data on the synthesis of the resin is listed in Table I. From Table I, we can see that when diallyl ether was employed as a crosslinking agent, the polymerization yield was very low, only $10 \%$. In contrast with diallyl ether, polymerization yield was higher when divinylbenzene was used as a crosslinking agent. In the polymerization system, toluene acts as a pore-creating agent. In the presence of toluene, the polymerization yield was high. Also, the prepared polymer possessed large specific surface area and high content of active carbonyl group.

Figure 1 shows SEM photographs of the polymer resins. The porosities on the surfaces of the polymer resins 1 and 3 were observed by SEM. Figure 2A shows an FT-IR spectrum of polymer resin 1 . In the spectrum, we observe the carbonyl band $\left(v_{\mathrm{C}=0}, 1730 \mathrm{~cm}^{-1}\right)$, the ester band $\left(v_{\mathrm{C}=0}, 1250 \mathrm{~cm}^{-1}\right)$, and the band of disubstituted benzene $\left(\delta_{\mathrm{C}-\mathrm{H}}, 835\right.$ and 802 $\left.\mathrm{cm}^{-1}\right)$.

Thus, polymer resin 1 (PAV) in Table I was selected as porous polymer carrier for immobilization. For the comparison in activity of immobilized enzyme, $\alpha$-chymotrypsin was also immobilized on polymer resin 3 (PA).

\section{Preparation of Porous Polymer Carrier}

The polymer resin PAV was reacted with $p$-nitroaniline under various conditions. The experimental data is listed in Table II. This macromolecular reaction was a heterogeneous reaction, because the resin was a crosslinked polymer insoluble to any organic solvents. So, the reaction hardly proceeded under mild conditions. When more severe condition was employed, the extent of reaction raised progressively as shown in the table. By using the data of nitrogen contents of the products and active carbonyl content of PAV, the highest extent of reaction was estimated to be approximately $80 \%$. In Figure $2 \mathrm{~B}$, the carbonyl band $\left(1730 \mathrm{~cm}^{-1}\right)$ evidently decreased, at the same time, the shiff base band $\left(v_{\mathrm{C}=\mathrm{N}}\right.$, $\left.1660 \mathrm{~cm}^{-1}\right)$ and the nitro band $(1510,1320$, and $750 \mathrm{~cm}^{-1}$ ) appeared. These data, thus, 
Immobilization of $\alpha$-Chymotripsin on Porous Carrier

Table I. Synthesis of the polymer resin ${ }^{a}$

\begin{tabular}{|c|c|c|c|c|}
\hline $\begin{array}{l}\text { Polymer } \\
\text { resin }\end{array}$ & Oil phase & $\begin{array}{l}\text { Dispersed } \\
\text { phase }\end{array}$ & Yield $/ \%$ & $\begin{array}{c}\text { active } \\
\mathrm{C}=\mathrm{O} / \%^{\mathrm{b}}\end{array}$ \\
\hline $\begin{array}{c}1 . \\
(\mathrm{PAV})\end{array}$ & $\begin{array}{l}0.12 \mathrm{~mol} \mathrm{Ac} \\
0.035 \mathrm{~mol} \mathrm{VAc} \\
0.021 \mathrm{~mol} \mathrm{DVB} \\
0.0027 \mathrm{~mol} \mathrm{AIBN} \\
10 \mathrm{ml} \text { Toluene }\end{array}$ & $\begin{array}{l}80 \mathrm{ml} \text { Water } \\
0.18 \mathrm{~g} \mathrm{SS}\end{array}$ & 98 & 13 \\
\hline 2. & $\begin{array}{l}0.12 \mathrm{~mol} \mathrm{Ac} \\
0.035 \mathrm{~mol} \mathrm{VAc} \\
0.021 \mathrm{~mol} \mathrm{DVB} \\
0.0027 \mathrm{~mol} \text { AIBN }\end{array}$ & $\begin{array}{l}80 \mathrm{ml} \text { Water } \\
0.18 \mathrm{~g} \mathrm{SS}\end{array}$ & 49 & 5.1 \\
\hline $\begin{array}{c}3 . \\
\text { (PA) }\end{array}$ & $\begin{array}{l}0.15 \mathrm{~mol} \mathrm{Ac} \\
0.0175 \mathrm{~mol} \mathrm{DVB} \\
0.0027 \mathrm{~mol} \mathrm{AIBN} \\
10 \mathrm{ml} \text { Toluene }\end{array}$ & $\begin{array}{l}80 \mathrm{ml} \text { Water } \\
0.18 \mathrm{~g} \mathrm{SS}\end{array}$ & 75 & 21 \\
\hline 4. & $\begin{array}{l}0.12 \mathrm{~mol} \mathrm{Ac} \\
0.035 \mathrm{~mol} \mathrm{VAc} \\
0.031 \mathrm{~mol} \text { DAE } \\
0.0027 \mathrm{~mol} \text { AIBN } \\
10 \mathrm{ml} \text { Toluene }\end{array}$ & $\begin{array}{l}80 \mathrm{ml} \text { Water } \\
0.18 \mathrm{~g} \mathrm{SS}\end{array}$ & 11 & 22 \\
\hline
\end{tabular}

a SS, soluble starch; AIBN, azobisisobutyronitrile; DAE, diallyl ether; Ac, acrolein; VAc, vinyl acetate.

$\mathrm{b}$ The active carbonyl content of the polymer was determined by the following reaction:

¿C $=\mathrm{O}+\mathrm{H}_{2} \mathrm{NOH} \cdot \mathrm{HCl}+\left(\mathrm{HOCH}_{2} \mathrm{CH}_{2}\right)_{3} \mathrm{~N} \rightarrow \mathrm{C}=\mathrm{NOH}+\left(\mathrm{HOCH}_{2} \mathrm{CH}_{2}\right)_{3} \mathrm{~N} \cdot \mathrm{HCl}+\mathrm{H}_{2} \mathrm{O}$

The polymer sample was reacted with analytical reagent (oxammonium hydrochloride and triethanolamine in ethanol) at $50^{\circ} \mathrm{C}$ for 3 hours, then the reaction system was titrated by standard hydrochloride when bromophenol blue as an indicator.

proves the occurrance of the desired reaction.

Under this reaction condition, poly(vinyl acetate) was simultaneously converted to poly(vinyl alcohol). In Figure 2B, the hydroxy band (1270 and $\left.1120 \mathrm{~cm}^{-1}\right)$ appeared, indicating the above transformation. Thus, the carrier was considered to be hydrophilic.

Figure 2C is FT-IR of the product reduced. In spectrum $\mathrm{C}$, the amino band $\left(v_{\mathrm{N}-\mathrm{H}}\right.$, $3500 \mathrm{~cm}^{-1}, 1240 \mathrm{~cm}^{-1}$ ) appeared, indicating the occurrance of reduction.

The porous polymeric carriers prepared from PAV and PA are denoted hereafter as CPAV and CPA, respectively.

\section{Immobilization of $\alpha$-Chymotrypsin}

Using CPAV and CPA as carriers, $\alpha$-chymotrypsin was immobilized by three meth- ods, namely (1) glutaraldehyde-crosslinking, (2) improved glutaraldehyde-crosslinking, and (3) diazo-coupling method. The experimental results are listed in Table III. There was the influence of steric hindrance resulting in difficulty for substrates to approach to the active site of enzyme. The activity of the immobilized enzyme using casein as a substrate was evidently lower than the activity using L-tyrosine ethyl ester by the effect of steric hindrance.

When L-tyrosine ethyl ester was used as a substrate, the immobilized enzymes obtained by various methods showed the differences in activity. Because of the higher steric hindrance of the stiff structure, the relative activity was low for the immobilized enzyme obtained by method 1 . The immobilized enzyme obtained 
G. TAO and S. FURUSAKI

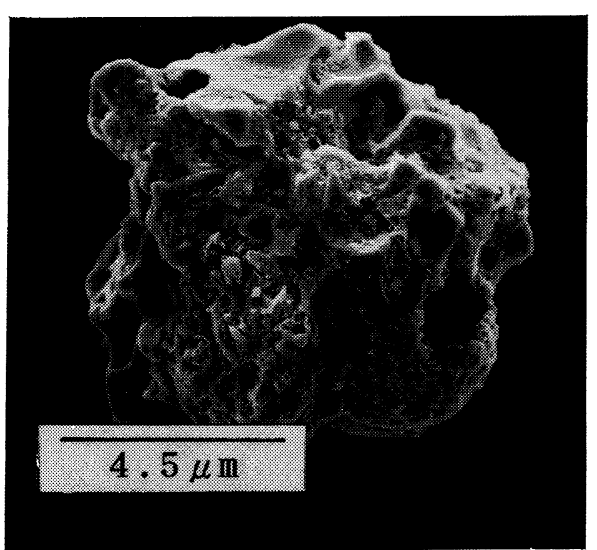

1

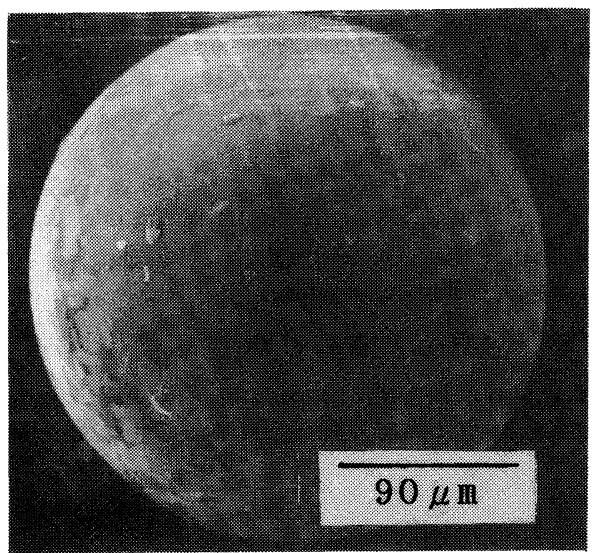

3

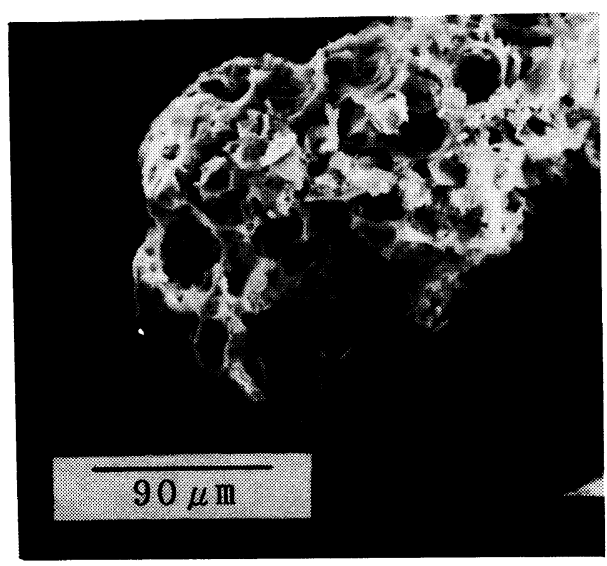

5

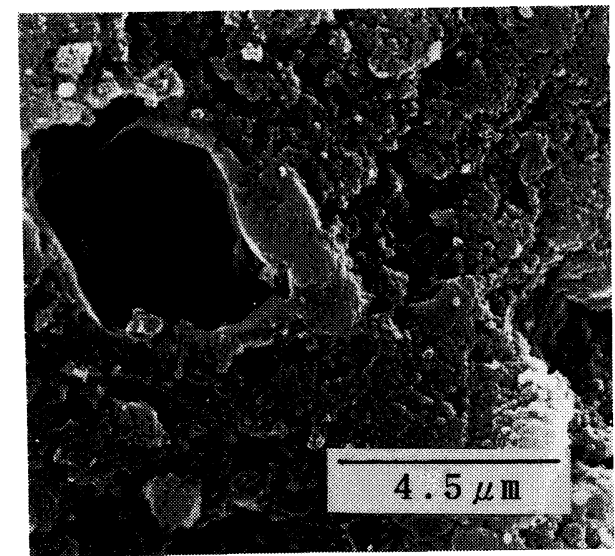

2

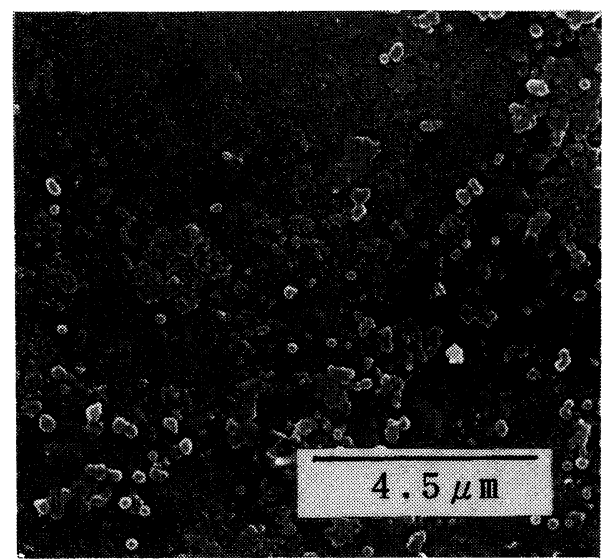

4

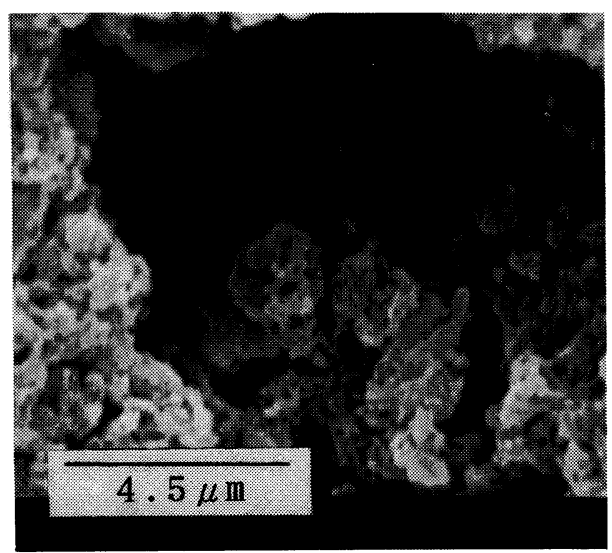

6

Figure 1. SEM photographs of the polymer resins. 1,2, polymer resin 1 (PAV); 3,4, polymer resin 2; 5,6 , polymer resin 3 (PA). 
Immobilization of $\alpha$-Chymotripsin on Porous Carrier

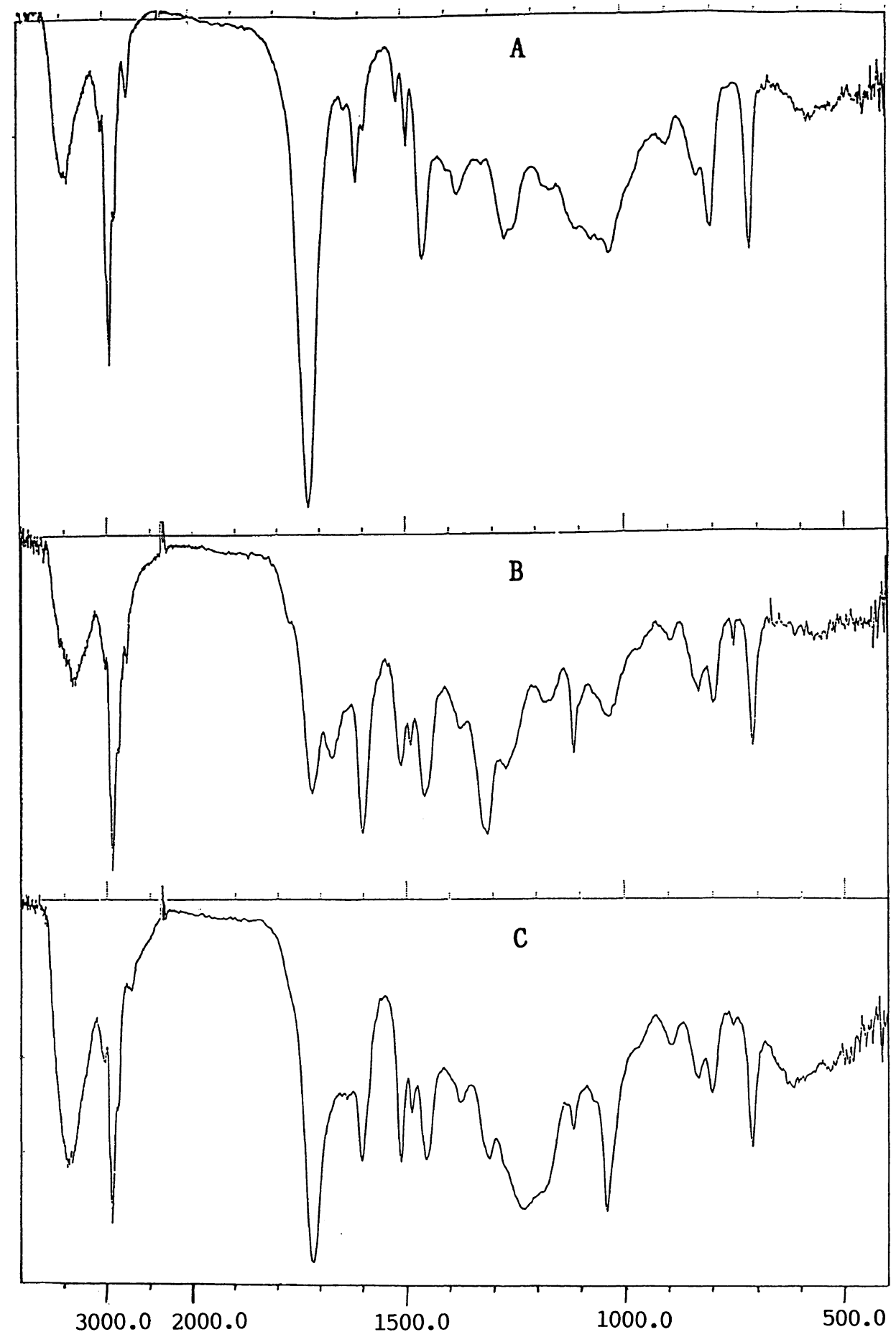

Figure 2. FT-IR spectra. A, PAV; B, product of PAV reacted with p-nitroaniline; C, reducted product. 
Table II. The reaction of PAV with $p$-nitroaniline

\begin{tabular}{|c|c|c|c|c|}
\hline $\begin{array}{l}\text { Reaction } \\
\text { medium }\end{array}$ & $\begin{array}{c}\text { Reaction } \\
\text { temperature } /{ }^{\circ} \mathrm{C}\end{array}$ & $\begin{array}{l}\text { Reaction } \\
\text { time } / \mathrm{h}\end{array}$ & $\begin{array}{l}\text { Nitrogen } \\
\text { content of } \\
\text { product } / \%\end{array}$ & $\begin{array}{l}\text { Extent of } \\
\text { reaction } / \%{ }^{\mathrm{a}}\end{array}$ \\
\hline $\mathrm{C}_{2} \mathrm{H}_{5} \mathrm{OH}$ & 50 & 12 & 0.63 & 7.5 \\
\hline iso- $\mathrm{C}_{3} \mathrm{H}_{7} \mathrm{OH}$ & 65 & 10 & 0.74 & 8.9 \\
\hline THF & Reflux & 12 & 1.54 & 18.4 \\
\hline $\mathrm{THF}+\mathrm{CH}_{3} \mathrm{COOH}$ & Reflux & 10 & 1.93 & 23.1 \\
\hline $\mathrm{C}_{2} \mathrm{H}_{5} \mathrm{OH}+\mathrm{HCl}$ & 70 & 8 & 3.08 & 36.8 \\
\hline $\mathrm{THF}+\mathrm{HCl}$ & Reflux & 10 & 3.09 & 37 \\
\hline iso- $\mathrm{C}_{3} \mathrm{H}_{7} \mathrm{OH}+\mathrm{HCl}$ & Reflux & 14 & 3.86 & 46.2 \\
\hline $\mathrm{DMF}+\mathrm{HCl}$ & 100 & 20 & 4.79 & 57.3 \\
\hline Dioxane $+\mathrm{HCl}$ & Reflux & 20 & 6.60 & 78.9 \\
\hline
\end{tabular}

${ }^{\text {a }}$ Calculated value based on the nitrogen content of product and the content of active carbonyl group.

Table III. Immobilization of $\alpha$-chymotrypsin

\begin{tabular}{|c|c|c|c|c|c|c|c|}
\hline \multirow{2}{*}{ IE } & \multirow{2}{*}{ Carrier } & \multirow{2}{*}{ Method } & \multirow{2}{*}{$\begin{array}{l}\text { Enzyme/carrier } \\
(\mathrm{mg} / \mathrm{mg})\end{array}$} & \multicolumn{2}{|c|}{$\mathrm{RA} / \%^{\mathrm{a}}$} & \multicolumn{2}{|c|}{$\mathrm{AR} / \%^{\mathrm{b}}$} \\
\hline & & & & Tyr-OEt & Casein & Tyr-OEt & Casein \\
\hline CPAV-1-E & CPAV & 1 & $1 / 50$ & 56 & 10 & 28 & 5 \\
\hline CPAV-2-E & CPAV & 2 & $1 / 50$ & 64 & 20 & 21 & 7 \\
\hline CPAV-3-E & CPAV & 3 & $1 / 50$ & 71 & 18 & 26 & 6 \\
\hline CPA-1-E & $\mathrm{CPA}$ & 1 & $1 / 50$ & 55 & 9 & 30 & 5 \\
\hline CPA-3-E & $\mathrm{CPA}$ & 3 & $1 / 50$ & 70 & 18 & 29 & 7 \\
\hline
\end{tabular}

a RA: Relative activity (\%)=activity of immobilized enzyme/(activity of free enzyme in solution-activity of free enzyme in filtration solution) $\times 100 \%$.

b AR: Activity recovery $(\%)=$ activity of immobilized enzyme/activity of free enzyme in solution $\times 100 \%$.

by method 3 possessed highest relative activity, the reason might be due to the lower immobilization temperature and the absence of denaturizing influence on enzyme by glutaraldehyde.

In respect of the activity recovery, the enzyme could be immobilized easily on the carrier because of high reactivity of diazo group. Thus, the activity recovery of immobilization method 3 was high. Although glutaraldehyde was employed as a crosslinking agent in methods 1 and 2, more enzyme was immobilized firmly on the carrier, so immobilization method 1 possessed the highest activity recovery.

When casein is used as a substrate, the immobilized enzymes obtained by the three methods showed different activities in compar- ison with the case when L-tyrosine ethyl ether was used as a substrate. This is the effect of steric hindrance as stated above. CPA has slightly higher functional group content than CPAV, so the immobilized enzyme using CPA as a carrier possessed slightly higher activity recovery.

Some factors which affect immobilization reactions are described below. In the following experiments, the enzyme activity was determined by the low molecular weight substrate at $25^{\circ} \mathrm{C}$.

\section{Effect of Glutaraldehyde Concentration}

Glutaraldehyde is a crosslinking agent for immobilization, but it will inactivate enzymes. The effect of glutaraldehyde concentration on immobilization by method 1 was investigated. 


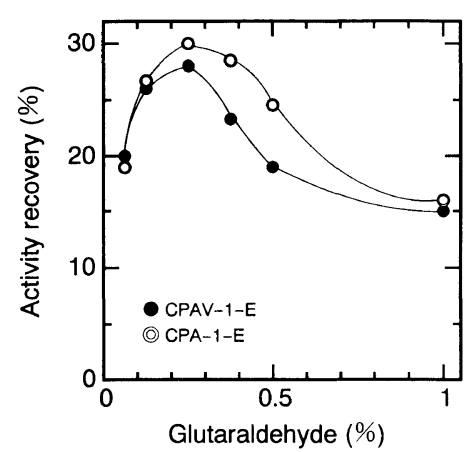

Figure 3. Effect of glutaraldehyde concentration on the activity recovery of immobilized enzymes. Immobilization: 6 hours at room temperature. Activity determination: L-TEE, 0.05 moll $^{-1}$ Tris $(\mathrm{pH}=7), 25^{\circ} \mathrm{C}$.

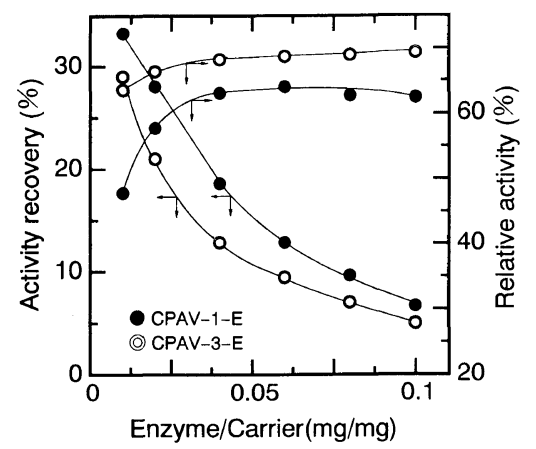

Figure 4. Effect of ratio of enzyme to carrier on the activity of immobilized enzymes. Immobilization condition: same as method 1. Activity determination: L-TEE, $0.05 \mathrm{moll}^{-1}$ Tris $(\mathrm{pH}=7), 25^{\circ} \mathrm{C}$.

Figure 3 shows that the optimum glutaraldehyde concentration exists for the immobilization reaction. When glutaraldehyde concentration in the immobilization system was $0.25 \%$, the immobilized enzymes reached the highest activity recovery.

\section{Effect of the Ratio of Enzyme to Carrier}

The enzyme was immobilized at different ratios of enzyme to carrier. The results are shown in Figure 4. When the ratio of enzyme/carrier was increased, the activity recovery of the immobilized enzyme decreased monotonously. At the same time, the relative activity remained almost constant with the

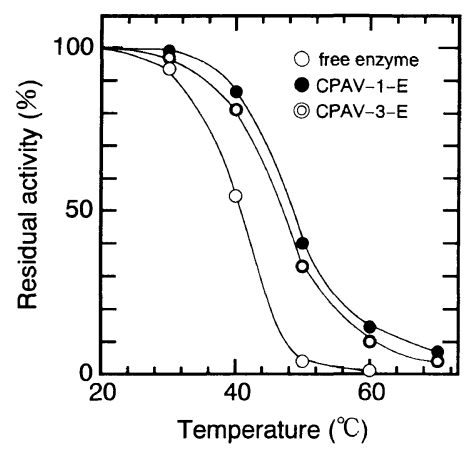

Figure 5. Thermal stability. Storage period: 1 hour. Activity determination: L-TEE, $0.05 \mathrm{moll}^{-1}$ Tris $(\mathrm{pH}=$ 7), $25^{\circ} \mathrm{C}$.

exception of a slight increase in the region of low ratios of enzyme/carrier. The reason might be that there is a limitation to combine the enzyme on the carrier due to the limited amount of the functional group.

\section{Stability and Reusability of the Immobilized Enzyme}

Thermal Stability. In the absence of substrate, the immobilized and free enzymes suspended in 0.05 moll $^{-1}$ Tris- $-\mathrm{HCl}$ buffer $(\mathrm{pH}$ 7.0) were kept at different temperatures for 1 hour, then cooled to $4^{\circ} \mathrm{C}$. After the treatment the residual activity was determined at $25^{\circ} \mathrm{C}$. The results (Figure 5) indicated that the residual activity of free enzyme rapidly decreased as the temperature increased, while that of the immobilized enzymes decreased slowly. Thus, the immobilized enzymes were found to be more stable than the free enzyme.

Storage Stability. After the immobilized and free enzymes were stored at $40^{\circ} \mathrm{C}$ in $0.05 \mathrm{moll}^{-1}$ Tris- $\mathrm{HCl}$ buffer ( $\mathrm{pH} 7.0$ ), the residual activity of enzyme was assayed at different intervals. The results (Figure 6) showed that the residual activity of the free enzyme was much lower than that of the immobilized enzymes. For example, when the storage period was 30 hours, the residual activity of the immobilized and free enzymes were $40 \%$ and $5 \%$, respectively. It is obvious 


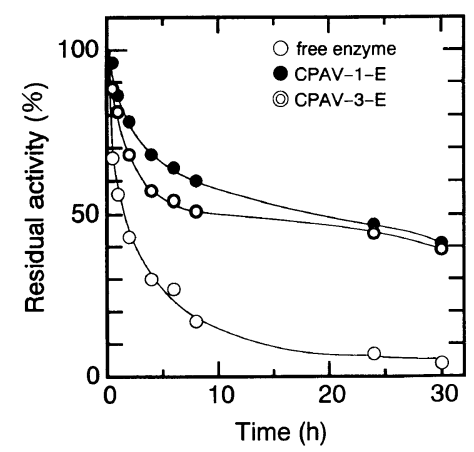

Figure 6. Storage stability. Storage temperature: $40^{\circ} \mathrm{C}$. Activity determination: L-TEE, $0.05 \mathrm{moll}^{-1}$ Tris $(\mathrm{pH}=$ 7), $25^{\circ} \mathrm{C}$.

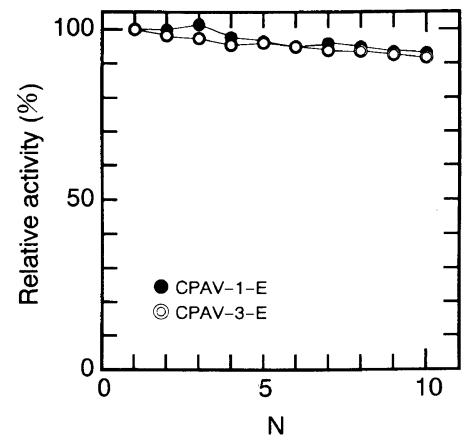

Figure 7. Reusability of immobilized enzymes. Activity determination: L-TEE, $0.05 \mathrm{moll}^{-1}$ Tris $(\mathrm{pH}=7), 25^{\circ} \mathrm{C}$.

that the immobilized enzymes are much more stable than the free enzyme.

\section{Reusability}

The reusability of the immobilized enzymes was determined at $25^{\circ} \mathrm{C}$, the used immobilized enzyme was washed twice with $0.05 \mathrm{moll}^{-1}$ Tris- $\mathrm{HCl}$ ( $\mathrm{pH} 7.0$ ), and then supplied again to the fresh reaction mixture to determine the enzymatic activity. This cycle was repeated. Figure 7 illustrates the effect of the repeated use on the residual activity of the immobilized enzymes. It can be seen that the activity of the immobilized enzymes hardly decreased after ten sequential uses.

The higher stability of the immobilized enzymes can be attributed to the prevention of autodigestion and thermal inactivation as a

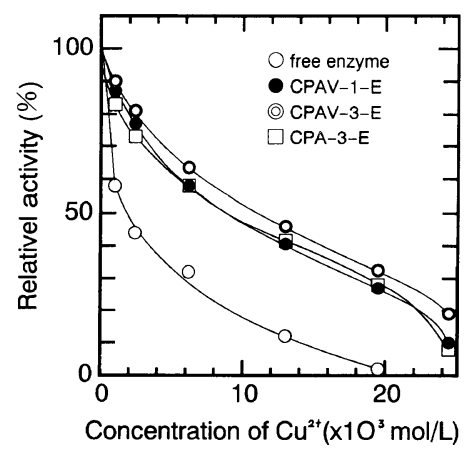

Figure 8. Effect of $\mathrm{Cu}^{2+}$ concentration on the activity of enzymes. Activity determination: L-TEE, $0.05 \mathrm{moll}^{-1}$ Tris $(\mathrm{pH}=7), 25^{\circ} \mathrm{C}$. Free enzymes concentration: 0.033 $\mathrm{mg} \mathrm{ml}^{-1}$. Immobilized enzymes concentration: $4 \mathrm{mg} \mathrm{ml}^{-1}$.

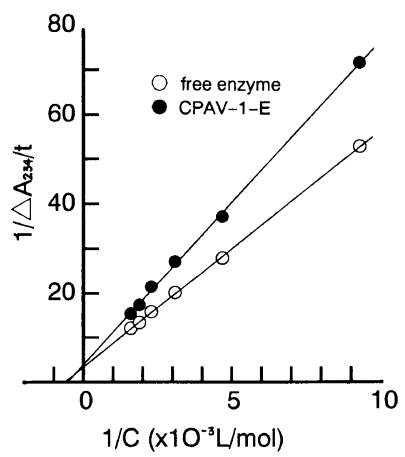

Figure 9. Lineweaver-Burk plots of the free and immobilized enzymes. Activity determination: L-TEE, 0.05 moll ${ }^{-1}$ Tris $(\mathrm{pH}=7), 25^{\circ} \mathrm{C}$. Free enzyme concentration: $0.016 \mathrm{mg} / \mathrm{ml}^{-1}$. Immobilized enzyme concentration: $4 \mathrm{mg} \mathrm{ml}^{-1}$.

result of the fixation of enzyme on the carrier. From the above experimental results, we can also observe that CPAV-1-E is slightly more stable than CPAV-3-E due to its stiff structure.

\section{Resistance against $\mathrm{Cu}^{2+}$ Inhibition}

It is known that heavy metal ions are inhibitors to $\alpha$-chymotrypsin, so we assayed the activity of the free and immobilized enzymes in the presence of different concentrations of $\mathrm{Cu}^{2+}$. Figure 8 shows that $\mathrm{Cu}^{2+}$ exerted an inhibitory effect on the immobilized enzymes, but the effect was smaller than that on the free enzyme. 
Michaelis Constant $K_{\mathrm{m}}$

Reaction rate was determined at different initial L-Tyr-OEt concentrations ranging from $0.1-0.65 \mathrm{mmoll}^{-1}$. Figure 9 shows the Lineweaver-Burk plots for the free and immobilized (CPAV-1-E) enzymes. The values of the apparent Michaelis constant $K_{\mathrm{m}}$ of the free and immobilized enzymes are estimated from Figure 9 to be $1.58 \times 10^{-3}$ and $1.86 \times$ $10^{-3} \mathrm{moll}^{-1}$, respectively. The apparent $K_{\mathrm{m}}$ value of the immobilized enzyme was higher than that of the free enzyme. The limitation of diffusional resistance might be one of the reasons. ${ }^{14}$

\section{CONCLUSIONS}

1. The polymeric resins, i.e., polyacrolein and polyacrolein-poly(vinyl acetate), were synthesized by radical suspension polymerization. When divinylbenzene was used as a crosslinking agent in the presence of porecreating agent, toluene, the yield of polymerization was higher and the obtained porous resin possessed larger active carbonyl content.

2. A porous polymer carrier was prepared by macromolecular reaction of the above resin with $p$-nitroaniline followed by reduction of the nitro group to amino group.

3. $\alpha$-Chymotrypsin was immobilized on the porous polymer carrier by the glutaraldehydecrosslinking method and the diazo-coupling method. The activity recovery and relative activity of the immobilized $\alpha$-chymotrypsin were determined. L-Tyrosine ethyl ester and casein were employed as low and high molecular weight substrates, respectively. The results indicated that the immobilized $\alpha$ chymotrypsin not only had higher relative activity but also had remarkable increase in the stability and good reusability. In addition, the immobilized enzyme had stronger resistance to the inhibitory effect of cupric ion.

Acknowledgments. G. Tao was supported to accomplish this study by Japan Society for the Promotion of Science (JSPS).

\section{REFERENCES}

1. J. F. Kennedy, C. A. White, and E. H. M. Melo, Chimicaoggi-Maggio, 21 (1988).

2. J. Cotte and Y. D'Audiffret, Riv. Ital. Essenze. Profum. Piante Offic. Aromi-Saponi-Cosmet., 59(3), 109 (1977).

3. J. E. Beckhorn, M. D. Labbee, and L. A. Underkofler, J. Agric. Food Chem., 13, 30 (1965).

4. J. A. Osborn and A. M. Yacynych, Anal. Chim. Acta, 183, 287 (1986).

5. H. Kise and A. Hayakawa, Enzyme Microbial. Technol., 13, 584 (1991).

6. T. Hayashi and Y. Ikada, Biotechnol. Bioeng., 35, 518 (1990).

7. T. Hayashi and Y. Ikada, Biotechnol. Bioeng., 36, 593 (1990).

8. H. Kise, Bioorg. Chem., 18, 107 (1990).

9. A. M. Klibanov, Chem. Technol., 16, 354 (1986).

10. J. P. O'Daly, A. L. Crumbliss, and R. W. Henkens, Biotech. Appl. Biochem., 12, 11 (1990).

11. D. H. Campbell, E. Luescher, and L. S. Lerman, Proc. Natl. Acad. Sci. U.S.A., 37, 575 (1951).

12. H. Bergmeyer, "Methods of Enzymatic Analysis," Academic Press, New York, N.Y., 1963, p 800.

13. J. Xu, J. Qi, and Z. Yuan, Shengwu Gongcheng Xuebao, 9(1), 69 (1993).

14. T. Hayashi, C. Hirayama, and M. Iwatsuki, J. Appl. Polym. Sci., 44, 143 (1992). 